\title{
Bureaucratic Corruption, Democracy and Judicial Independence
}

\author{
Gang Wang ${ }^{1}$ \\ ${ }^{1}$ Department of Political Science, University of Zurich, Switzerland \\ Correspondence: Gang Wang, Department of Political Science, University of Zurich, Switzerland. E-mail: \\ wang.ucb@gmail.com
}

Received: January 13, 2016 Accepted: January 18, 2016 Online Published: February 26, 2016

doi: 10.20849/abr.v1i1.11 URL: http://dx.doi.org/10.20849/abr.v1i1.11

\begin{abstract}
The theoretical literature in economics and political science has made numerous efforts in understanding the determinants of corruption and stressed the importance of political institutions in shaping the patterns of government corruption. Nevertheless, very few researches focus on the role of judicial system. Employing a formal model with empirical analyses, I incorporate economic factors with political constraints to investigate the different roles of democracy and judicial independence in determining the level of bureaucrats' corruption across countries. Empirically, the instrumental variable (IV) approach is applied to resolve the endogeneity problems. The evidence indicates that different levels of corruption across countries are significantly influenced by the degrees of judicial independence. To fight corruption successfully, I contend that the judiciary, as a hard institutional constraint to resist bureaucratic corruption, has to be independent from the government.
\end{abstract}

Keywords: bureaucratic corruption, judicial system, economic factors, constraints

\section{Introduction}

Corruption, as government officials use public powers for private economic interests, has been the hot topic of debate among social scientists. Evidence of bureaucratic corruption exists in all economies, at various stages of development, and under different political and economic regimes. But why is it more pervasive in some societies than in others? Economists and political scientists have stressed the importance of such variables as economic development, government expenditure, democracy, checks and balances, etc. Comparatively very few scholars focus on the role of judicial system in shaping the patterns of bureaucratic corruption. Employing a formal model with empirical analyses, the author incorporated economic factors with political constraints to investigate the different effects of democracy and judicial system on the level of corruption and argue the judiciary, as a hard institutional constraint to resist bureaucratic corruption, has to be independent from the government.

For most economists, corruptions lie in the delegation of power. Therefore, economic theories pay much attention to the decision of rational bureaucrats who involved in corrupt transactions. Under information asymmetry, the principal in many cases may not have full control over the agent's misconduct. Thus the agent can circumvent many of the checks and controls that are placed by the principal (Rose-Ackerman, 1978). It is easier to explain the nature of corruption according to the failure of the principal-agent relationship. It is, however, unclear why officials in some countries misuse public office for private gain more frequently and for larger payoffs than their counterparts in others. Thus a principal-agent model has its limitations in explaining the level of corruption.

Many economists have also studied the empirical regularities between corruption and a variety of economic variables across the countries. Most of these studies report income (Damania et al., 2004; Lederman et al., 2005; Treisman, 2000), government expenditure (Fishman \& Gatti, 2002), and economic freedom (Goldsmith, 1999; Park, 2003; Treisman, 2000) have a negative-significant effect of the level of corruption. However, some economic factors like government expenditure which is significant in a particular model may lose their significance when some other political variables are incorporated. Hence as Seldadyo and Haan (2006) contend, "claims concerning the determinants of corruption are conditional, and the robustness of the findings is open to question."

Political scientists have been attempting to explain how political institutions influence actual corruption levels in different societies. The logic that political institutions play a key role in fighting bureaucratic corruption is reasonable and obvious. Because government intervention transfers resources from one party to another, it 
creates room for corruption (Acemoglu \& Verdier, 2000). Since in a modern society it is unavoidable that the government frequently involves in economic activities, without any political constraints, government leaders can make full use of public resources for private benefits. In other words, without a strict punishment which can only be offered by political institutional arrangements, corruption will be out of control. But various political institutions may have very different effects on bureaucrats' corruption behavior. For instance, under a judicial system, a corruptive bureaucrat will be punished severely based on solid evidence of his corruptive activities whereas under democratic system, a corruptive bureaucrat can only be punished via free press exposure and voting outcomes. Generally speaking, the actual level of corruption in a society should be determined by the strictest of institutional arrangements. Many comparative studies report a significant relationship between democracy and the level of corruption based on various regression approaches without controlling judicial independence. In my view, these empirical conclusions on the "Democratic Clean Theory" are theoretically and empirically problematic.

The structure of the rest part is organized as follows: in Section two, I am going to analyze the flawed logic and empirical paradox of democratic clean theory. In Section three, a formal model will be employed to investigate why the level of judicial independence rather than democracy has a significant impact to the level of corruption. My empirical evidence will be provided in Section four and the brief discussion and conclusion in the end.

\section{The Flawed Logic and Empirical Paradox of Democratic Clean Theory}

Following the logic of the Principle-Agent Model, many political scientists argue that a democratic regime predicts a low level of corruption because electoral accountability enforces an efficient constraint to government officials and political competition and free press reduce information asymmetries between voters and bureaucrats (A. D. Tella, 1997, 1999; B. D. Tella, 2004; Chang-Golden, 2004; Goldsmith, 1999; Gurgur-Shah, 2005; Ackerman, 2005; Lederman et al., 2005; Treisman, 2000). Theoretically the corruption level of a country is determined by the most efficient political constraint to bureaucrats' misconduct. Thus the democratic clean theory is reasonable given that the democratic regime is the strictest of institutional arrangements. Unfortunately, thus far there is no literature articulately comparing the efficiency of democracy and that of judicial independence in term of fighting corruption. In addition, without a judicial intervention, whether electoral accountability and free press imply a high expected cost for the bureaucrat is in doubt. As Rose-Ackerman (1999) concluded, the distinctive incentives for corruption in democracies depend on the organization of electoral and legislative processes and on the methods of campaign finance (Note 1). Hence democratic elections are not invariably a cure for corruption.

The empirical evidence of a relationship between democracy and corruption is also mixed. While many regression analyses find that democracy has significant impacts on the level of corruption (Aidt \& Dutta, 2001; Emerson, 2006; Ferejohn, 1986; Lederman et al., 2001; Sandholtz \& Koetzle, 2000). A cross-national study by Treisman (2000) suggests that the current degree of electoral democracy is not significantly correlated with the level of corruption, but long exposure to democracy predicts lower corruption. Montinola and Jackman (2002) confirm that political competition affects levels of corruption, but this effect is nonlinear. Most of these studies employ OLS regression analyses without controlling the level of judicial independence. Since many measures of political institutions are highly associated with each other and endogenous relationships among aggregate level variables are very popular in social science research, the strategy of research design is crucial to the credibility of empirical results.

Because I am interested in not only the determinants of corruption from comparative perspective, but the causal mechanisms between bureaucrats' corruption behavior and institutional arrangements, I attempt to employ a formal model to further our understanding on bureaucratic corruption and then provide a robust empirical analysis.

\section{Corruption and Political Constraints}

Under certain economic conditions, a bureaucrat's corruptive behavior is a rational decision based on cost-benefits consideration. Because political institutions define the rules of game in delegation of power, and anyone breaks the rules may be enforced a penalty, a bureaucrat should consider political constraints as corruptive action costs. We can observe how the bureaucrat searches for his perfect corruption level by analyzing his utility function.

Assume a bureaucrat's expected wage income was $W_{0}$ in time period $t$ without corruption. With corruption his income in the two states, "no punishment" $\left(W_{1}\right)$ and "punishment" $\left(W_{2}\right)$, is $\left(W_{0}+\alpha, W_{0}+\alpha-\alpha_{I}\right)$, where 
$\alpha$ represents the benefits from corruption and $\alpha_{I}$ the punishment enforced by a political institution. Since not all corruptive activities can be monitored, the expected utility theorem suggests that his preferences for income in these two states are described by the following function,

$$
V\left(p, W_{1}, W_{2}\right)=(1-p) U\left(W_{1}\right)+p U\left(W_{2}\right),
$$

Where $U()$ represents the utility of money income and $p$ the probability of being punished. Bureaucrats' corruption behavior can be seen as a choice between different combinations of the potential corruption levels and punishments, which can be described by $V\left(p, \alpha, \alpha_{I}\right)=V\left(p, W_{0}+\alpha, W_{0}+\alpha-\alpha_{I}\right)$. From all the corruption-punishment choices the bureaucrat is offered, he chooses the one that maximizes $V\left(p, \alpha, \alpha_{I}\right)$. Since he always has the option of doing no corruption, a bureaucrat will select corruption only if $V\left(p, \alpha, \alpha_{I}\right) \geq V(p, 0,0)=U\left(W_{0}\right)$, which implies that bureaucrats are willing to work in public sectors because they can enjoy high rents by using public offices or public sectors could offer an efficiency wage. I assume that bureaucrats are identical in all aspects and that they are risk-averse $\left(U^{\prime \prime}<0\right)$.

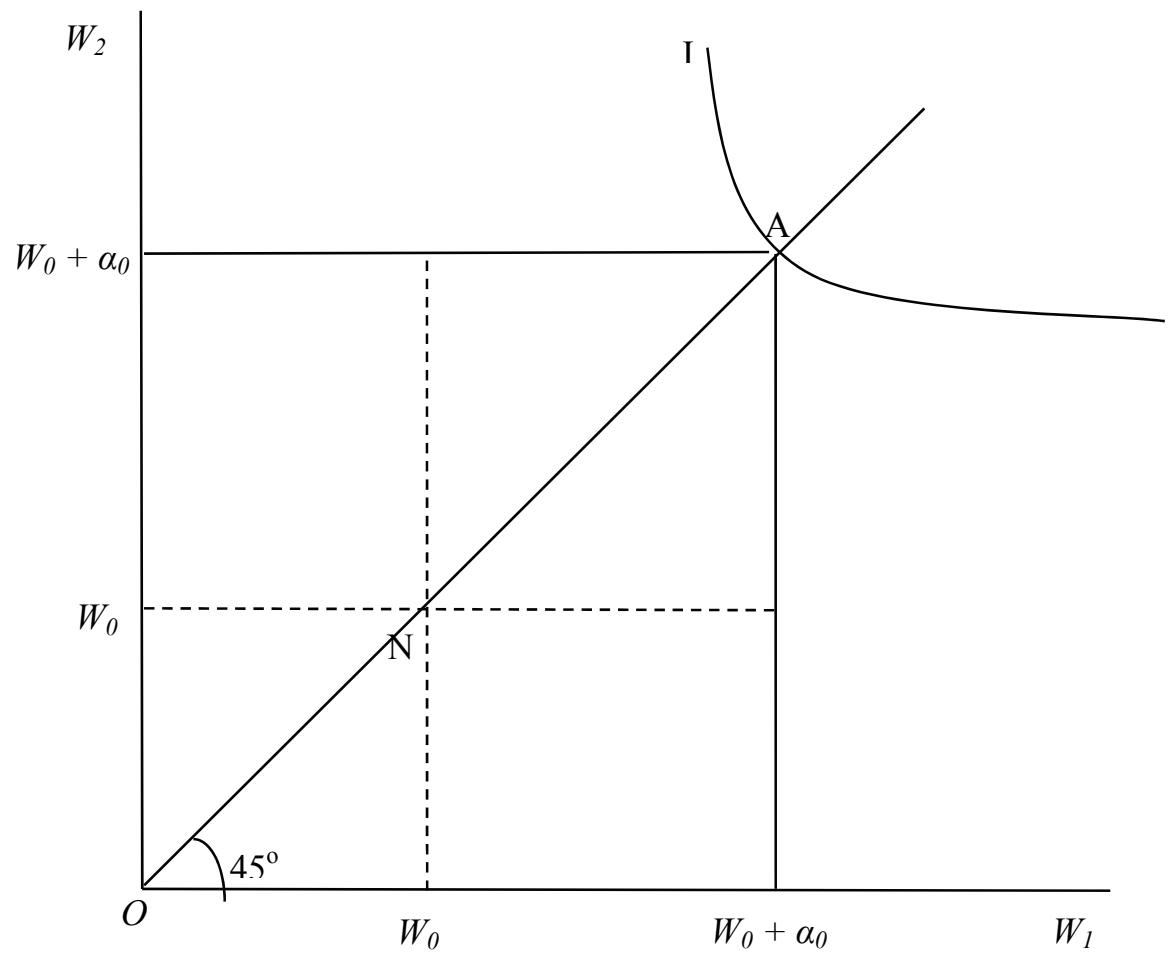

Figure 1.

Suppose the amount of public resources he can corrupt is $\alpha_{0}$. In Figure 1, let's try to understand a bureaucrat's behavior in this way: to gain the corrupt benefit $\alpha$ (on the horizontal axes), $0 \leq \alpha \leq \alpha_{0}$, he has to pay the cost of being punished $\alpha_{I}$ with probability $p$, so the expected cost will be $p \times \alpha_{I}$ (on the vertical axes). 
Assume his corrupt behavior will never be tolerated, so the probability of being detected is equal to the probability of being punished (see Note 2-1 for proof). If there are no institutional constraints, $p=0, \alpha_{I}=0, p \times \alpha_{I}=0$, then $V\left(p, W_{1}, W_{2}\right)=U\left(W_{0}+\alpha\right)$ and from $\frac{\partial U\left(W_{0}+\alpha\right)}{\partial \alpha}>0$, which implies he enjoys every dollar corrupted without paying any cost. In figure 1, the rational bureaucrat will get started from point $N\left(W_{0}, W_{0}\right)$ and go along with the straight line $N A$ until point $A\left(W_{0}+\alpha_{0}, W_{0}+\alpha_{0}\right)$ is reached. That is, the rational bureaucrat can maximize his utility under the initial budget line $N A$. At point $A\left(W_{0}+\alpha_{0}, W_{0}+\alpha_{0}\right)$, he makes full use of public resources for private gains and his utility in this circumstance is $V_{A}\left(p, W_{1}, W_{2}\right)=(1-p) U\left(W_{1}\right)+p U\left(W_{2}\right)=U\left(W_{1}\right)=U\left(W_{0}+\alpha_{0}\right)$

\subsection{Bureaucrats' Corruption Behavior under Democracy}

Now suppose an institutional arrangement, democracy emerges. Consider whether democratic elections can reduce the amount of corruption significantly. The mechanisms of democracy over corruption are as follows:

1) Electoral Accountability. Identical voters elect government officials. When voters have a signal of a bureaucrat misusing public office for private benefits, no matter what's the amount of corruption, he will lose his job. Since there is no judicial intervention so far, the most severe and only punishment for him is always to be fired. Assume his wage income in office at the time period $t_{1}$ is $W_{1}$; the probability of winning the election again at the end of $t_{1}$ is $\pi$. So the expected total income after $t_{1}$ is $\pi \times W_{t}$ if he wins the election. If he loses the election, he could find another position in the job market and the expected income in the new position will be $\delta \times \pi \times W_{t}$, where $\delta$ is a discount number and $\delta \in[0,1]$. Now his expected wage income in $t_{1}$ is $W_{1}+\pi \times W_{t}$ without corruption. With corruption his income in the two states "no punishment" and "punishment" is:

$$
\left(W_{1}+\pi \times W_{t}+\alpha, \quad W_{1}+\delta \times \pi \times W_{t}+\alpha\right)=\left(W_{1}+\pi \times W_{t}+\alpha, W_{1}+\pi \times W_{t}+\alpha-(1-\delta) \times \pi \times W_{t}\right)
$$

Suppose $\delta, \pi, W_{t}$ are all exogenous variables and they are uncorrelated with $\alpha$. Let $W_{0}=W_{1}+\pi \times W_{t}$, and $\alpha_{d}=(1-\delta) \times \pi \times W_{t}$. The bureaucrat corruption choices can be described as $\left(W_{0}+\alpha, W_{0}+\alpha-\alpha_{d}\right)$, where $W_{0}$ and $\alpha_{d}$ are both constants. Generally speaking, in modern societies, a government official's wage income is much less than the public resources under his control. That is, $\alpha_{0}>W_{0} \geq \alpha_{d}$.

2) Monitor System. Because of free press and political competition, the probability of his corruption behavior being detected in a democratic regime $\left(p_{D}=p_{D}(\alpha)\right)$ is reasonably higher than that in an autocracy. $p_{D}(\alpha)$ 
can be understood as an information function, and $p^{\prime}{ }_{D}(\alpha)>0,0=p_{D}(0) \leq p_{D}(\alpha) \leq p_{D}\left(\alpha_{0}\right)=1$. The nature of $p_{D}(\alpha)$ is that although there is information asymmetry between voters and bureaucrats, voters can get incomplete information through free press and party competition. When the bureaucrat is doing corruption, the information will accumulate as $\alpha$ increases, so $p^{\prime}{ }_{D}(\alpha)>0$. In addition, as $\Delta \alpha$ increases, I assume $\Delta p$ will be larger, so $p^{\prime \prime}(\alpha) \geq 0$. The notion of this assumption is that when a monitoring system finds his corruption behavior, it not only has the information for his current performance, but will actively collect more information about his previous behavior to find out whether he did corruption before.

Now the bureaucrat's preferences for corruption can be described by the following function:

$$
\begin{gathered}
\left\{\begin{array}{l}
\operatorname{Max} V\left(p_{D}, \alpha\right)=\left(1-p_{D}(\alpha)\right) \times U\left(W_{0}+\alpha\right)+p_{D}(\alpha) \times U\left(W_{0}+\alpha-\alpha_{d}\right) \\
\text { S.t. }\left(1-p_{D}(\alpha)\right) \times\left(W_{0}+\alpha\right)+p_{D}(\alpha) \times\left(W_{0}+\alpha-\alpha_{d}\right) \geq W_{0}
\end{array}\right. \\
\Leftrightarrow\left\{\begin{array}{l}
\operatorname{Max} V\left(p_{D}, \alpha\right)=\left(1-p_{D}(\alpha)\right) \times U\left(W_{0}+\alpha\right)+p_{D}(\alpha) \times U\left(W_{0}+\alpha-\alpha_{d}\right) \\
\text { S.t. } \alpha-p_{D}(\alpha) \times \alpha_{d} \geq 0
\end{array}\right.
\end{gathered}
$$

Notice the political implication of $p^{\prime}{ }_{D}(\alpha)$ is the marginal probability of being punished when the bureaucrat enjoys one more dollar corruption income, thus $p^{\prime}{ }_{D}(\alpha)$ is a very small number even though $p_{D}^{\prime}(\alpha)>0$ and $p^{\prime \prime}(\alpha) \geq 0$. From $\alpha-p(\alpha) \times \alpha_{D} \geq 0$ (see Note 2-2 for proof), his corruption behavior now is converted into a single purpose nonlinear programming problem and the optimal level of corruption is determined by the shape of $V\left(p_{D}, \alpha\right)$ and $\alpha-p_{D}(\alpha) \times \alpha_{d}$.

Define the bureaucrat's Arrow-Pratt coefficient of absolute risk aversion at $\alpha$ as $r_{A}(\alpha)=-u^{\prime \prime}(\alpha) / u^{\prime}(\alpha)$. Given that the bureaucrat is not highly risk averse and the marginal probability $p^{\prime}{ }_{D}(\alpha)$ is a small number, specifically, when $p^{\prime}(\alpha)<\frac{1}{\alpha_{d}}=(1-\delta) \times \pi \times W_{t}$ and

$$
r_{A}(\alpha)=-u^{\prime \prime}(\alpha) / u^{\prime}(\alpha) \leq \frac{p^{\prime \prime}(\alpha)}{2 p^{\prime}(\alpha)}+\frac{(1-p(\alpha)) U^{\prime \prime}\left(W_{0}+\alpha\right)+p(\alpha) U^{\prime \prime}\left(W_{0}+\alpha-\alpha_{d}\right)}{2 p^{\prime}(\alpha)\left[U\left(W_{0}+\alpha-\alpha_{d}\right)-U\left(W_{0}+\alpha\right)\right]}
$$

we can prove institutional constraint $\alpha-p_{D}(\alpha) \times \alpha_{d}$ is a monotone increasing function of $\alpha$ and $V^{\prime}\left(p, W_{1}, W_{2}\right)>0$ in $\left[0, \alpha_{0}\right]$ (see Note 2-3 for proof), which implies as the marginal budget keeps going up, a bureaucrat will always enjoy every dollar from the corruption income. Therefore there is no Interior 
Solutions but a Corner Solution $\alpha=\alpha_{0}$ (the equilibrium $\mathrm{E}_{\mathrm{d}}$ in Figure 2) for the bureaucrat under a democracy constraint and

$$
V_{D-\operatorname{Max}}(\alpha)=\left(1-p_{D}\left(\alpha_{0}\right)\right) \times U\left(W_{0}+\alpha_{0}\right)+p_{D}\left(\alpha_{0}\right) \times U\left(W_{0}+\alpha-\alpha_{d}\right)=U\left(W_{0}+\alpha_{0}-\alpha_{D}\right)
$$

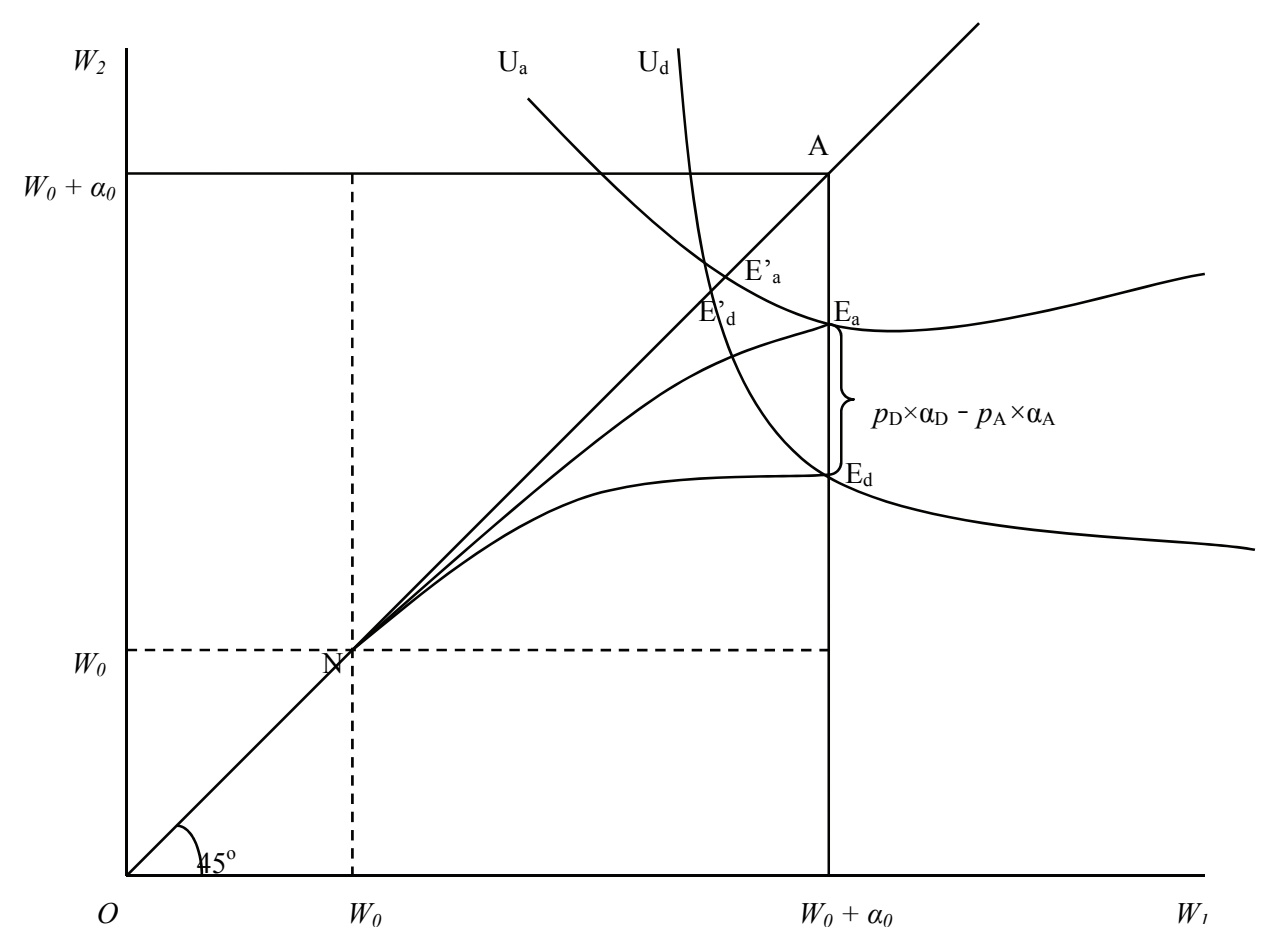

Figure 2.

Similarly, if we assume in an autocracy, the corresponding punishment and the probability of being punished is relatively smaller, we can see that the bureaucrat still fixes his level of corruption at $\alpha_{0}$.

$$
\begin{gathered}
V_{A-\operatorname{Max}}(\alpha)=\left(1-p_{A}\left(\alpha_{0}\right)\right) \times U\left(W_{1}\right)+p_{A}\left(\alpha_{0}\right) \times U\left(W_{2}\right) \\
=U\left(W_{0}+\alpha_{0}-\alpha_{A}\right) \\
V_{A-\operatorname{Max}}(\alpha)-V_{D-\operatorname{Max}}(\alpha)=U\left(W_{0}+\alpha_{0}-\alpha_{A}\right)-U\left(W_{0}+\alpha_{0}-\alpha_{D}\right)>0
\end{gathered}
$$

The bureaucrat in a democracy has to pay much more cost (the expected punishment), thus his expected utility might be smaller than his counterparts in an autocracy. Since $\frac{p_{D}(\alpha)}{1-p_{D}(\alpha)}>\frac{p_{A}(\alpha)}{1-p_{A}(\alpha)}$, his indifference curve looks steeper in a democracy and people become a little more risk-averse. But the actual level of corruption does not change from an autocracy to a democracy. 
In Figure 2, we can see the different institutional arrangements change the bureaucrat's budget line in different ways. Now the bureaucrat is trying to maximize his utility under a new budget line $N E_{d}$ or $N E_{a}$ rather than $N A$. However, any institutional arrangement which can decrease the level of corruption significantly has to increase the expected punishment (corruption cost) at least beyond the bureaucrat's expected corruption benefit at the low level of corruption. In other words, the new budget line has to be below the horizontal line $W_{0} N$ since a certain low level of corruption. Theoretically, any corner solutions except $N$ cannot reduce corruption, so a good institutional design should lead us to find the possible interior solutions and the actual levels of corruption in different countries are determined by the potential interior solution and thus the proposed institution.

Basically we have two approaches to threaten the bureaucrat's corruption behavior. This first one is to increase the punishment $\alpha_{d}$. But as $\alpha_{d}$ is a constant and exogenous variable, without a new institution intervention, electoral accountability has little influence to $\alpha$. Even a democracy could raise the penalty, this potential punishment is hard to be equivalent to the one that judicial system can offer. On the other hand, we may also strengthen the monitoring capability and inspect every dollar government expended, as some other scholars have argued, free press and party competition is important to limit the scope of corruption. But the embarrassment is that monitoring bureaucrats' behavior is just a prerequisite or necessary condition of penalty. When democratic punishment cannot threaten bureaucrats' vital interests, how can we expect to see a sufficient better outcome emerging? That's why I will focus on the role of judicial independence in the following section.

\subsection{Fighting Corruption: The Role of Judicial Independence}

In political science literature, judicial independence usually refers to the autonomy of judges, which implies the members of the judiciary ought to have an independent relationship with other parts of the political system and they can expect their decisions to be implemented free from any outside pressure (Russell, 2001). The mathematical form of judicial independence can be expressed as follows in the sense of fighting bureaucratic corruption.

Suppose $\alpha$ represents the mount of public resources which have been corrupted, and $L(\alpha)$ is a punishment

for his behavior defined by law. $L(\alpha)+\varepsilon$ is the real punishment made by judges, where $\varepsilon$ is a random error. Then judicial independence refers to:

$$
E(L(\alpha)+\varepsilon)=E(L(\alpha))+E(\varepsilon)=E(L(\alpha))=L(\alpha)
$$

Because a normal form of government intervention in judicial system is to decrease punishment, we can introduce $G(\alpha)<0$ as a measure of judicial dependence. When judges' decision is influenced by the government, the expected punishment for a bureaucrat will be:

$$
E(L(\alpha)+G(\alpha)+\varepsilon)=E(L(\alpha))+E(G(\alpha))+E(\varepsilon)=L(\alpha)+G(\alpha)<L(\alpha)
$$

Basically, we can use the similar logic to analysis the role of judicial independence, and the bureaucrat's strategy is still to select the perfect level of corruption under punishment constraints. But there are two differences between democratic constraint and judicial constraint. The first one is the promising punishment is not a constant 
in the judicial system. The more the public resources corrupted, the more severe punishment will be given to him. So $\alpha_{J}$ is a monotone increasing function of $\alpha$. Because the independent judicial system can enforce a strict sanction on government officials, we define the sanction function $\alpha_{J}=J(\alpha)>\alpha$ for any $\alpha \in\left[0, \alpha_{0}\right]$ and $J(0)=0$ (no corruption, no punishment), $J^{\prime}(\alpha)>0$. In addition, once all the public resources are corrupted, the bureaucrat will receive a more severe punishment, $J\left(\alpha_{0}\right)-\left(W_{0}+\alpha_{0}\right)>0$. To simplify our analysis, let $J^{\prime \prime}(\alpha)=0$, which implies the anti-corruption law will not increase the marginal punishment to the bureaucrat suddenly because he received one more dollar illegal income. The second difference is that courts have to have substantial evidences to prove he misused public resources for personal benefits, so the probability of being monitored, and hence the probability of being punished will be much smaller in the judicial system, but we still have $p_{J}^{\prime}(\alpha)>0$.

Now the bureaucrat's preferences for corruption under judicial constraint can be described by the following function:

$$
\begin{gathered}
\left\{\begin{array}{l}
\operatorname{Max} V\left(p_{J}(\alpha), \alpha\right)=\left(1-p_{J}(\alpha)\right) \times U\left(W_{0}+\alpha\right)+p_{J}(\alpha) \times U\left(W_{0}+\alpha-J(\alpha)\right) \\
\text { S.t. }\left(1-p_{J}(\alpha)\right) \times\left(W_{0}+\alpha\right)+p_{J}(\alpha) \times\left(W_{0}+\alpha-J(\alpha)\right) \geq 0
\end{array}\right. \\
\Leftrightarrow\left\{\begin{array}{l}
\operatorname{Max} V\left(p_{J}(\alpha), \alpha\right)=\left(1-p_{J}(\alpha)\right) \times U\left(W_{0}+\alpha\right)+p_{J}(\alpha) \times U\left(W_{0}+\alpha-J(\alpha)\right) \\
\text { S.t. } \quad \mathrm{W}_{0}+\alpha-p_{J}(\alpha) \times J(\alpha) \geq 0
\end{array}\right.
\end{gathered}
$$

So his optimal corruption behavior is also converted into a single purpose nonlinear programming problem, and there is one and only one interior solution $\alpha^{* * \in}\left(0, \alpha_{0}\right)$ (see Note iv for proof).

Now suppose the levels of judicial independence are different in two countries A and B. We can substitute $J_{A}(\alpha)=L_{A}(\alpha)+G_{A}(\alpha)$ and $J_{B}(\alpha)=L_{B}(\alpha)+G_{B}(\alpha)$. Other things being equal, if $J_{B}(\alpha) \leq J_{A}(\alpha)$ then we predict the bureaucratic corruption will be more pervasive in country B than in country A. That is $\alpha_{B} * *>\alpha_{A} * *$.

Figure 3 presents some intuitionistic notions of why an independent judicial system can reduce the level of corruption efficiently and determine the different levels of corruption across countries. In figure 3, compared to the democratic constraint, there is an inflection point in the judicial budget line because the strictest punishment is always enforced by judicial system, so even when the probability of being punished is relatively small, the bureaucrat is facing a high cost of corruption behavior. To see this, let's compare the features of different budget lines:

In a democracy: 


$$
\frac{\partial\left(\alpha-p_{D}(\alpha) \times \alpha_{d}\right)}{\partial \alpha}>0 \text { and } \frac{\partial^{2}\left(\alpha-p_{D}(\alpha) \times \alpha d\right)}{\partial \alpha^{2}}<0
$$

In a judicial constraint,

$$
\begin{gathered}
\frac{\partial^{2}\left(\alpha-p_{J}(\alpha) \times J(\alpha)\right)}{\partial \alpha^{2}}<0 \text { but } \\
\frac{\partial\left(\alpha-p_{J}(\alpha) \times J(\alpha)\right)}{\partial \alpha}>0 \text { when } \alpha \text { is small and } \\
\frac{\partial\left(\alpha-p_{J}(\alpha) \times J(\alpha)\right)}{\partial \alpha}<0 \text { when } \alpha \text { is very large }
\end{gathered}
$$

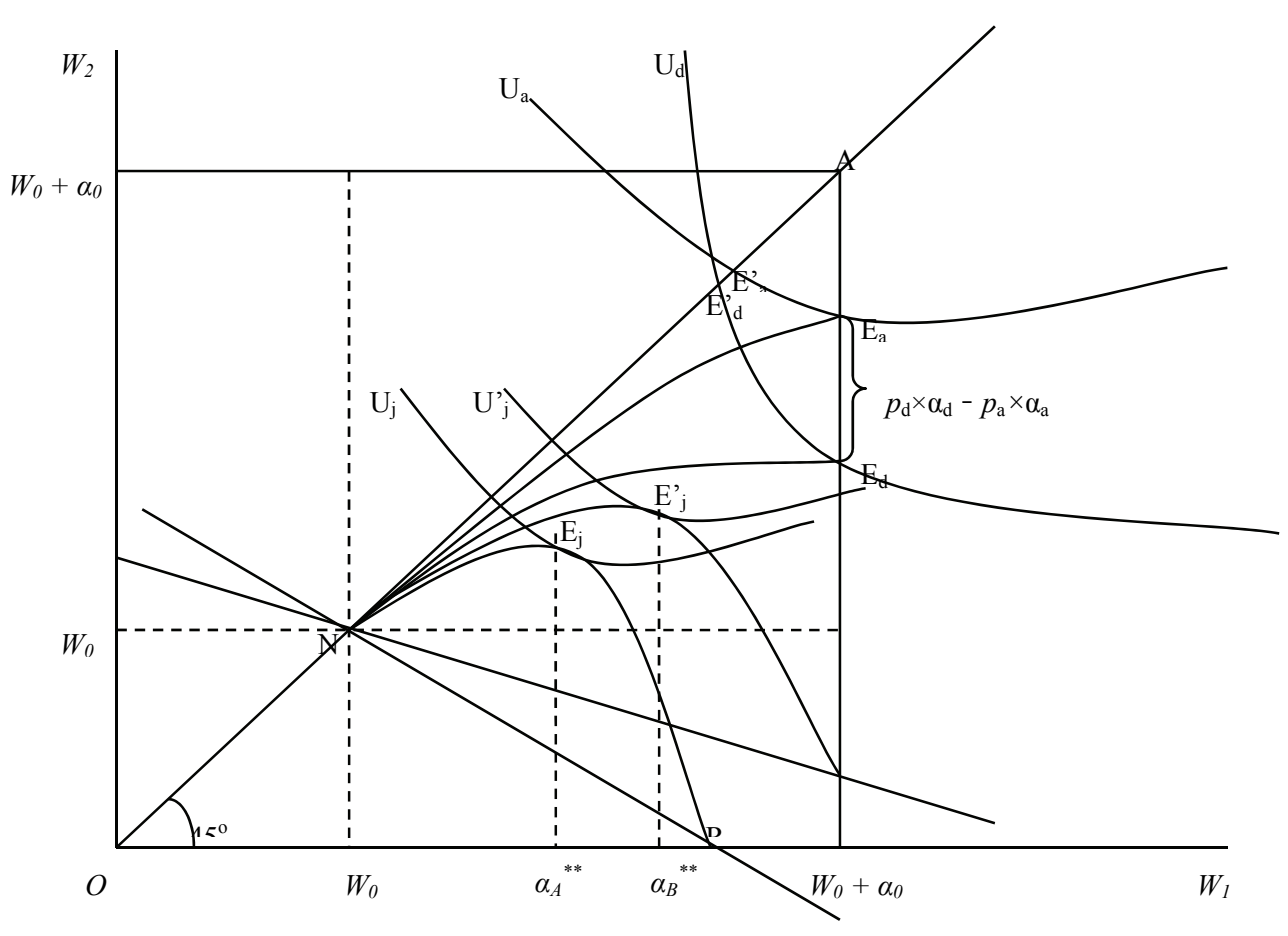

Figure 3.

Basically, the shape of judicial constraint line is influenced by two factors, the monitoring technology and the level of judicial independence. So my findings provide a new support for the arguments that the monitoring technology matters to the level of corruption. The joint effect of the monitoring technology and judicial independence determines the equilibrium when economic variables are held as constants. Under certain monitoring technology, an efficient way to influence the bureaucrat's behavior is to change the punishment. Let $J(\varepsilon)=+\infty$ for any $\varepsilon>0$. That is, any corruption behavior once monitored will be enforced a horrible penalty. $W_{0}+\varepsilon-p_{J}(\varepsilon) \times J(\varepsilon) \rightarrow-\infty$, so the rational bureaucrat won't do any corruption. Graphically, this 
budget line will be the vertical line $N W_{0}$. In this case, the equilibrium will be $N\left(W_{0}, W_{0}\right)$, which implies there is no corruption.

In most countries, even with $J_{i}(\alpha)=L_{i}(\alpha)+G_{i}(\alpha)<L_{i}(\alpha)$, as long as there is an inflection point in the judicial budget line, the different levels of corruption will be predicted by the levels of judicial independence.

\section{Empirical Analyses}

\subsection{A Simple Model of Corruption}

In previous analyses, I do not consider the effects of economic variables on the amount of corruption. However, both the wage income $W_{0}$ and the amount of public resources under bureaucrats control $\left(\alpha_{0}\right)$ can influence the actual level of corruption. Therefore, corruption can be identified as a product in a certain society with specific economic and political structures. Suppose $E$ and $P$ respectively represent the amount of economic and political resources controlled by government bureaucrats. Symbol " $A$ " refers to an overall measure of the institutional environment, or to what extent bureaucrats may easily make use of public responsibility for private ends. I assume the aggregate level of bureaucratic corruption can be described by the following Cobb-Douglas production function:

$$
\text { Corruption }=A \times E^{\alpha} \times P^{\beta}
$$

Where $\alpha$ denotes the index that bureaucrats use public economic resource for personal purposes or interests. $E^{\alpha}$ thus refers to how much public resources have been corrupted due to economic conditions. Similarly, $\beta$ denotes the index that bureaucrats use public political resources for personal purposes or interests. $P^{\beta}$ thus refers to how much public political resource has been corrupted under certain political environment.

$$
\begin{aligned}
& \text { Corruption }=A \times E^{\alpha} \times P^{\beta} \\
& \log (\text { Corruptio } \quad n)=\log (A)+\alpha \times \log (E)+\beta \times \log (P)
\end{aligned}
$$

Because bureaucrats always have motivations to convert the public resources into private ends, $\alpha>0$ and $\beta>0$, I expect to see the level of corruption is positively associated with the economic and political resources under the government's control.

\subsection{A Brief Review of Literature on Judicial Independence (JI)}

It is well recognized that the rule of law is the cornerstone of a prosperous society. Among various aspects of law, JI is considered to be a foundation for the rule of law (United Nations, 1985). Most political scientists believe that the separation of powers and checks and balances is essential for a regime to be well-functioning. As one of the most effective checks and balances, the independence of the judiciary can prevent the abuse of government power by other political branches.

The literature has not reached the consensus on the definition of JI. Some scholars have produced long lists of criteria the judiciary must meet, whereas others focus on more narrow aspects of judicial institutions (Landes \& Posner, 1975; Larkins, 1996; Shetreet, 1985). According to the number of characteristics involved, JI can be defined in the following ways.

The first type of definition deals with two levels of characteristics: judge and judiciary level (Abbasi, 2008). The independence of judge refers to the impartiality of judicial decision. That is, the results of a court should not be intervened by the judge's personal interest in the outcome of the case. On the contrary, the independence of judiciary, autonomy, is defined from the institutional perspective. It refers to the relationship between the judiciary and political branches. In other words, specific arrangements are created to prevent the political forces from becoming the main determinants of judicial behavior. In literature, the independence of judge is 
synonymous to decisional independence, whereas the independence of judiciary is identical to institutional independence.

The second type of definition includes three characteristics. According to the World Bank, the judicial independence includes three dimensions: impartiality, compliance with the judicial decisions, and free from interference from other political branches. Impartiality refers to the situation in which the results of a court are not influenced by the judge's personal interest. The compliance with the judicial decisions implies that judicial decisions should be well respected once they are rendered. Insulating judges from interference of government officials is often taken to be the most important aspect of judicial independence. Similar definition is also provided by Greene (2006). Based on interviews of Canadian appellate court judges, Greene (2006) also identified three aspects of judicial independence: impartiality, no interference from other judges, and complete freedom to decide.

Another innovative definition is put forward by Rios-Figueroa. He (2005) proposed to unpack the concept of JI into four components: autonomy, external independence, internal independence, and the institutional location of the public prosecutor's office. Autonomy refers to the relation between the judiciary and the elected branches of government. External independence refers to the relation between Supreme Court judges and government branches, whereas internal independence is the relation between lower court and supreme. As for the institutional location of the public prosecutor's office, the author sets three categories: within the judiciary, the executive, or as an autonomous organ. If judges and prosecutors belong to the same judiciary, they would be more independent of political powers from other government organs.

In my analysis, I adopt the definition that JI has two characteristics: decisional independence and institutional independence. In line with these two dimensions of JI, I am motivated to find two sources of exogenous variations in political institution to instrument JI. The first instrument-tenure of Supreme Court judges, indicates the decisional independence, whereas the second instrument-the year of the constitution significantly revised last time, represents the institutional independence.

\subsection{Research Design}

A lot of research has been conducted empirically to uncover the causal effect of specific political institutions on corruption. My interest in this paper is to identify the causal effect of judicial system on the outcome of corruption. However, cross-country analysis often faces an obstacle, the endogeneity problem if I simply employ an OLS regression. First, it is confronted by the simultaneity problem. There are unobservable variables that may determine both the decision to form the judicial system and the level of corruption. The second issue is concerned with reverse causality: a change in corruption level may lead to a change in the decision to outline the judicial structure. It is quite likely that high-income economies with low level of corruption can afford better judicial system. These endogeneity problems put threat to internal validity of my study, and become the biggest concern for the research design of my study.

A well-known strategy to resolve the endogeneity issue is to use instrumental variables (IV). The two IVs used in my analysis are the year of the constitution significantly revised last time, and tenure of Supreme Court judge. For abbreviation, the first IV is called YCR, and the second IV is called tenure. The logic is that YCR does not affect the corruption level of countries directly, but countries whose constitution were significantly revised more recently tend to have less stable judiciary system and less rigidity of constitution. The volatile judiciary system indicates a weak judicial independence. Similarly, tenure of judges does not influence the bureaucrats' corruptive behavior directly, but longer terms for judges provide greater job security so that judges' concerns about holding their position or being promoted do not influence their decisions, which may further lead to the independence of judiciary.

Specifically, the IV approach will proceed in two steps: in the first step, the judicial independence variable is regressed on YCR, tenure and other observable exogenous regressors; in the second step, the predicted value of the judicial variable is used in the corruption regression. The validity of IV will be discussed in detail in the following sections.

\subsection{Data and Descriptive Statistics}

Table 1 provides descriptive statistics for the key variable of interest. The Corruption Perceptions Index in 2006 is my measure of corruption outcome, ranging from 1.8, the most corrupt country Haiti, to 9.6, the cleanest country New Zealand. My key explanatory variable is the level of judicial independence in 2005, with a range of 0.3 to $9.2,0.3$ corresponding to the least judicial independent country Venezuela and 9.2 referring to the most judicial independent country Germany. The IV variables-YCR spans almost two centuries, varying from 1814 to 
2005; and Tenure ranges from 0 to 2 , with 0 representing a tenure less than six years, 1 indicating a tenure more than six years but not life long, and 2 representing life long. Since CPI 2006 actually refers to the corruption level in the year of 2005 in different countries, all the independent variables in my empirical study are measured in 2005 .

Table 1. Descriptive statistics

\begin{tabular}{cccccc}
\hline Variable & Obs. & Mean & Std. Dev. & Min & Max \\
\hline CPI 2006 & 162 & 4.100617 & 2.155867 & 1.8 & 9.6 \\
Log(GDP) & 165 & 8.584104 & 1.18453 & 6.39693 & 10.9836 \\
Government Size & 136 & 6.054412 & 1.306103 & 2.4 & 9.3 \\
Government Consumption & 138 & 5.976087 & 2.047272 & 0 & 10 \\
Government Investment & 129 & 5.209302 & 3.358 & 0 & 10 \\
Judicial Independence & 119 & 4.880672 & 2.338052 & .3 & 9.2 \\
Political Rights & 164 & 3.457317 & 2.148906 & 1 & 7 \\
Civil Liberty & 164 & 3.256098 & 1.801914 & 1 & 7 \\
YCR & 165 & 1992.921 & 21.59804 & 1814 & 2005 \\
Tenure & 130 & 1.407692 & .7334336 & 0 & 2 \\
\hline
\end{tabular}
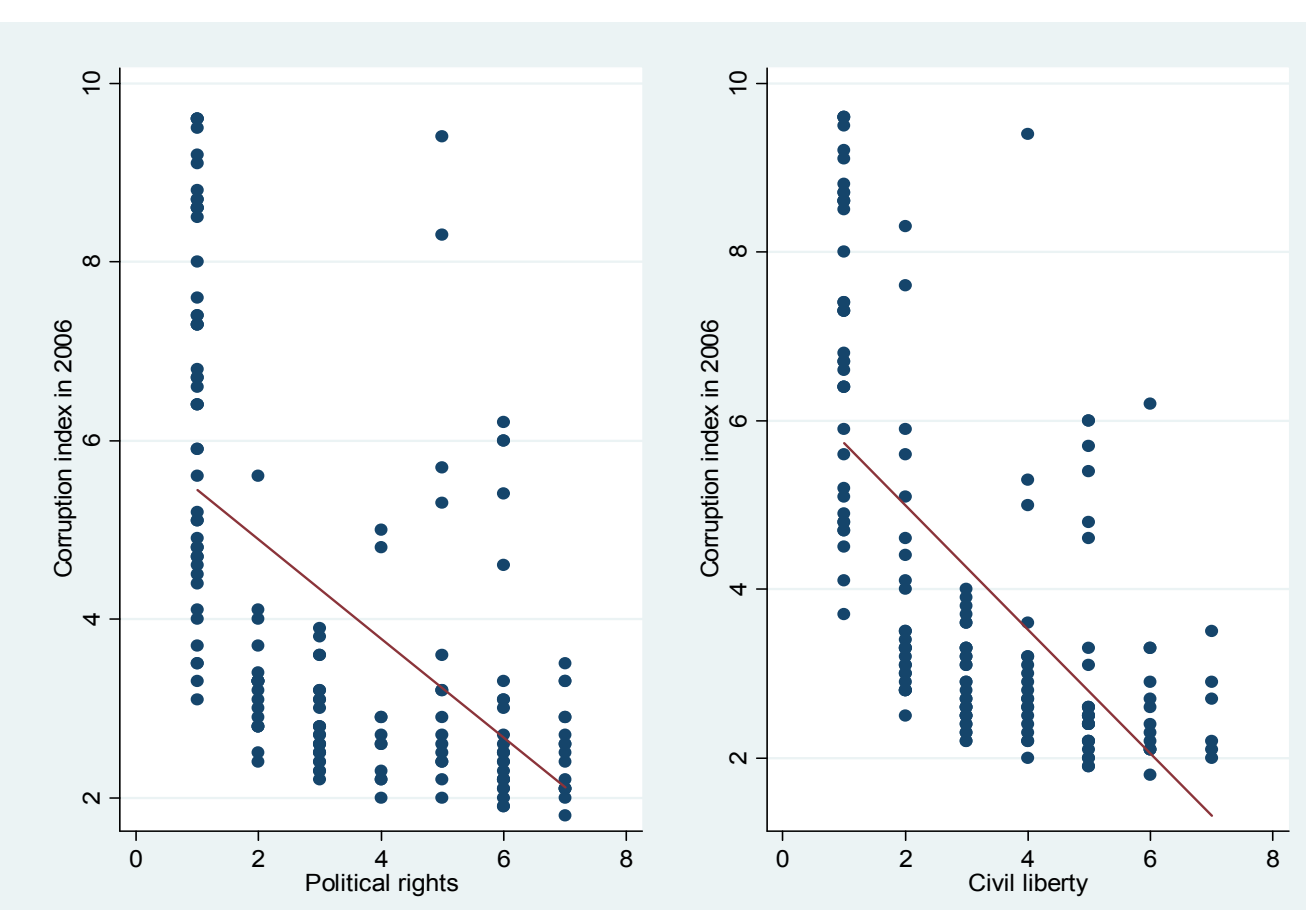

Figure 4. Reduced-form relationship between corruption index and democracy (political rights or civil liberty) 


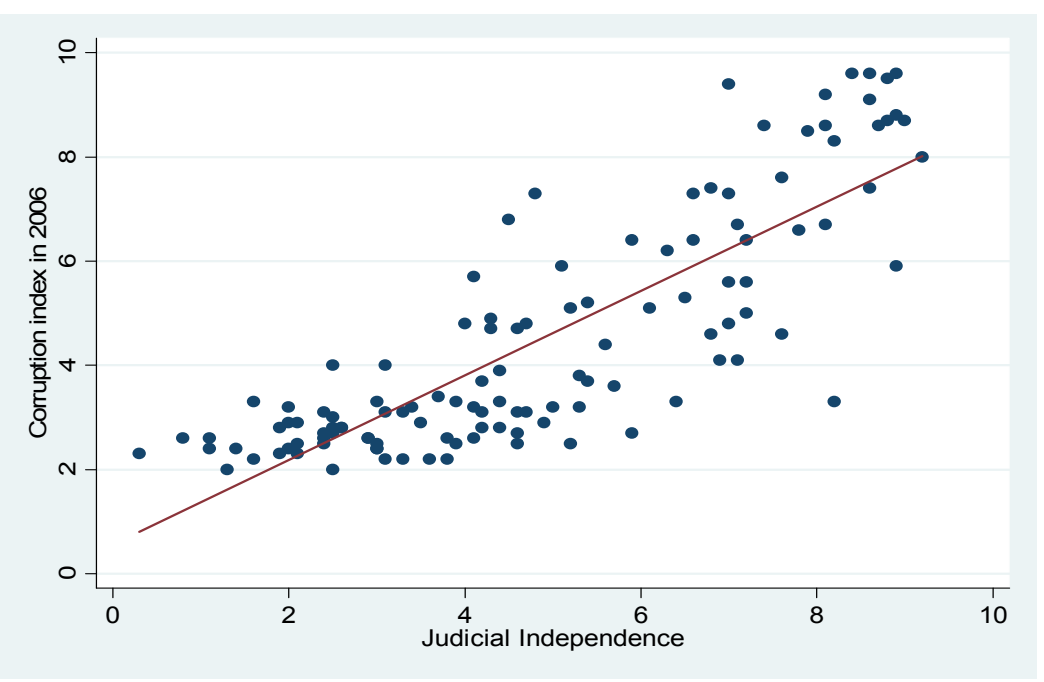

Figure 5. Reduced-form relationship between corruption index and judicial independence

Which institution is more effective in fighting corruption: democracy or judicial independence? Figures 4 \& 5 present simple graphic illustrations of the relative efficiency of these two institutions. Figure 4 plots the corruption index in 2006 against two measures of democracy: political rights and civil liberty. It shows a very weak association between corruption and democracy regardless of which measure of democracy is applied. In sharp contrast, Figure 5 presents a strong positive association between corruption and judicial independence. Countries with higher level of judicial independence present a lower level of corruption. Naturally, I conclude that democracy has a weaker impact on reducing corruption, while judicial independence has a stronger impact on it. The next section will provide regression results to substantiate this statement.

Figure 6 plots the CPI 2006 against the year when the current constitution was significantly revised last time for a sample of 165 countries (two countries with YCR in the 1800s are dropped out of the graph). It shows a strong negative relationship between these two variables. Countries which revised their constitution more recently are substantially more corrupt than countries which revised current constitution many years ago. To validate this, I will regress current corruption level (in 2006) on current judicial independence level (in 2005), and instrument the latter by YCR and tenure variables. The IV regression result will be presented in the following sections.

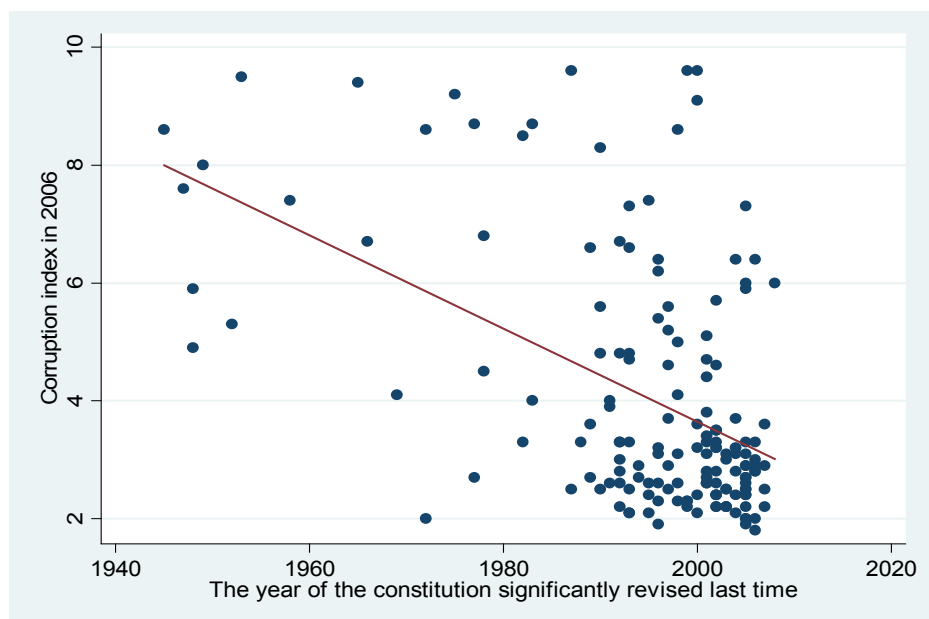

Figure 6. Reduced-form relationship between corruption index and YCR (IV) 


\subsection{Ordinary Least-Squares Regressions}

In this part, I will present the naive result from OLS regression in Table 2. The basic specification is listed as follows:

$$
\text { Corruption }=\mu+\alpha \times \text { Judicial_Independence }_{i}+X_{i}^{\prime} \beta+\varepsilon_{i}
$$

Where Corruption $_{i}$ is the dependent variable, indicating the corruption level in 2006 for country i; Judicial_Independence $e_{i}$ is my key explanatory variable, indicative of the judicial independence level of country $\mathrm{i}$ in 2005. I use the lagged values instead of current values of Judicial_Independence to capture the causal effect. $X_{i}$ is a vector of other covariates, including logarithm of GDP $\mathcal{E}_{i}$ government size, government consumption, government investment, political rights, and civil liberty; and $\mathcal{E}_{i}$ is a random error term. The coefficient of interest throughout the paper is $\alpha$, the effect of judicial independence on the level of corruption. Table 2 reports the OLS regression estimates of corruption on democracy, judicial independence, and other controls.

First, the effect of democracy on controlling corruption is not effective. Political rights variable has insignificant effect against corruption no matter whether the level of judiciary independence is controlled (see Model 2 and Model 4). Yet civil liberty, another measure of democracy, is statistically significant in Model 2, which excludes judiciary level.

Second, the coefficient of judicial independence variable, an estimate of 0.464 , shows its strong positive association with the dependent variable CPI 2006. Further, once the judiciary level is controlled, two measures of democracy become insignificant. The overall OLS results indicate the correct predication of my formal model. Compared to democracy index, judicial independence can explain the differences of corruption across countries much better.

Table 2. OLS regression analyses (dependent variable: CPI 2006)

\begin{tabular}{lllll}
\hline & Model 1 & Model 2 & Model 3 & Model 4 \\
\hline Independent Variables & & & & \\
Log(GDP) & $1.250^{* * *}$ & $1.118^{* * *}$ & $0.842^{* * *}$ & $0.794^{* * *}$ \\
Government Size & -0.203 & -0.114 & -0.155 & -0.121 \\
Government Consumption & -0.072 & -0.112 & -0.005 & -0.023 \\
Government Investment & $0.148^{*}$ & 0.102 & $0.102^{*}$ & 0.087 \\
Judicial Independence & & & $0.475^{* * *}$ & $\mathbf{0 . 4 6 4 * * *}$ \\
Political Rights & & 0.228 & & 0.102 \\
Civil Liberty & & $-0.445^{*}$ & & -0.194 \\
Adj R & & 0.7153 & 0.8243 & 0.8229 \\
\hline
\end{tabular}

Significant level: $* * * \mathrm{p}<0.001,{ }^{* *} \mathrm{p}<0.01,{ }^{*} \mathrm{p}<0.05$

\subsection{Judicial Independence and Corruption: IV Results}

As I discussed in the Research Design section, the endogeneity problems will bias the OLS result and make the OLS estimates inconsistent. Therefore, in order to estimate the impact of political institution on corruption level, I need find a source of exogenous variation in political institution, an instrumental variable (IV), to remove the spurious correlation between the explanatory variable and unobserved characteristics. The two instruments I am using are YCR, the year of a country's constitution significantly revised last time, and tenure, term of judges. Conceptually, the IV approach imply that, in the first stage, a variable which is unrelated to the outcome variable is used as a predictor of the key explanatory variable; in the second stage, the outcome variable is regressed on 
the predicted measure from the first stage.

But, the validity of inferences from an IV analysis depends on the appropriateness of the exclusion restriction assumption, which imply that, conditional on the controls included in the regression, YCR and tenure have no effect on corruption level today (in 2006), other than their effect through the institutional development of judicial independence.

The two-stage least-squares estimates are presented in Table 3. JudicialIndependence $e_{i}$ is treated as endogenous and modeled as following:

$$
\text { JudicialIndependence }_{i}=\varsigma+\theta_{1} * Y C R_{i}+\theta_{2} * \text { Tenure }_{i}+X_{i}^{\prime} \pi+v_{i}
$$

Where $Y C R_{i}$ is the year when a country's constitution was significantly revised last time, and Tenure $_{i}$ is the tenure of Supreme Court judges. The exclusion restriction is that these two variables do not appear in equation (1)

Table 3. IV (2SLS) Regression of corruption (dependent variable: CPI 2006)

(Instrumented: Judicial Independence 2005)

(IV: YCR and tenure)

\begin{tabular}{lllll}
\hline & Model 1 & Model 2 & Model 3 & Model 4 \\
\hline Independent Variables & & $.579^{*}$ & $.393^{* *}$ & $.553^{* *}$ \\
Log(GDP) & & -.121 & & -.111 \\
Government Size & & .094 & .085 \\
Government Consumption & & .051 & & .049 \\
Government Investment & & $.849^{* *}$ & $.919^{* * *}$ & $\mathbf{. 8 5 3 * *}$ \\
Judicial Independence & $1.103^{* * *}$ & & .099 & .110 \\
Political Rights & .078 & & -.134 & -.136 \\
Civil Liberty & -.152 & & 0.7225 & 0.7523 \\
Adj R & 0.6104 & 0.7588 & & \\
\hline
\end{tabular}

Significant level: $* * * \mathrm{p}<0.001,{ }^{* *} \mathrm{p}<0.01,{ }^{*} \mathrm{p}<0.05$

The corresponding 2SLS estimate of the impact of judicial independence on corruption in model 4 is 0.853 (standard error $=0.328$ ), which is larger than the OLS estimate 0.464 reported in Table 2 (model 4). This suggests the downward bias of OLS estimates. In addition, the existence of attenuation bias, and the measurement error in the judicial independence variable is likely to be more important than reverse causality and omitted variable biases. It is plausible that one single measure of political institution can hardly capture the whole set of political institutions that matter for corruption level. The IV approach presents us a more credible estimate.

I perform two types of tests to consolidate my IV results. First, I test the null hypothesis of exogeneity of judiciary independence variable. If this null is not rejected, the analysis will proceed under the assumption of exogeneity and run OLS regressions. Otherwise, the analysis will proceed to do IV. Typically, Hausman test will accomplish this task. Second, the over-identification test is performed. Since I have only one potential endogenous variable but have two candidate instruments, I need test the exogeneity of the extra instruments. That is, whether all of the instruments are valid.

The Hausman test presents a chi-square value of 9.63 with a P-value of 0.0012 , indicating rejection of the consistency of OLS and support for using IV regression. The over-identification test has a P-value of 0.895 , 
which is highly insignificant. So at the typical $5 \%$ significance level, I would fail to reject the hypothesis that the instrumental variables are all exogenous. These two instruments turn out to be valid for my analysis.

\section{Discussion and Conclusion}

It is widely discussed that differences in institutions are at the root of large differences in economic outcome across countries. However, plagued with endogeneity problems, it is difficult to isolate exogenous sources of variation in institutions to estimate their effect on economic performance. Employing a simple formal model as micro foundation, this paper particularly focuses on the causal effect of judicial independence status on the corruption level. Two instrumental variables: the year when a country's current constitution was significantly revised last time, and tenure of judges, serve as a source of exogenous differences in judicial independence level. However, these two IVs do not directly influence corruption level. Thus, the exclusion restriction assumption is met. The estimates are robust across various specifications. The research findings indicate that a severe punishment enforced by independent judicial system is necessary to deter bureaucrats' corruption behavior, and different levels of corruption across countries can be explained much better than democracy does.

There are many questions left unanswered in this paper. In the formal model, it is assumed that government officials are identical in all aspects and they are risk-averse. In reality, different bureaucrats in similar positions may present different attitudes towards the potential sanction of risk. In addition, informal institutions such as culture and customs were not considered to influence bureaucrats' corruption behavior in the formal model and empirical analyses. These questions leave room for the future study.

\section{References}

Ades, A., \& Rafael, T. (1996). The Causes and Consequences of Corruption: A Review of Recent Empirical Contributions. In B. Harris-White \& G. White (Eds). Liberalization and the New Corruption. Brighton: Institute of Development Studies Bulletin.

Ades, A., \& Rafael, T. (1999). Rents, Competition, and Corruption. The American Economic Review, 89(4), 982-993. http://dx.doi.org/10.1257/aer.89.4.982

Aidt, T. S. (2003). Economic Analysis of Corruption: A Survey. The Economic Journal, 113, 32-52.

Azfar, O. et al. (2001). The Causes and Consequences of Corruption. Annals of the American Academy of Political and Social Science, 573, 42-56. http://dx.doi.org/10.1177/000271620157300103

Bardhan, P. (1997). Corruption and Development: A Review of Issues. Journal of Economic Literature, 35, $1320-1346$.

Colander, D. (1984). Neoclassical Political Economy: The Analysis of Rent-seeking and DUP Activities. Mass: Ballinger Publishing Co.

Damania, R., Fredriksson. P., \& Mani, M. (2004). The Persistence of Corruption and Regulatory Compliance Failures: Theory and Evidence. Public Choice, 121, 363-390. http://dx.doi.org/10.1007/s11127-004-1684-0

De Mello, L., \& Barenstein, M. (2002). Fiscal Decentralization and Governance: A Cross-Country Analysis. In G. T. Abed, \& S. Gupta (Eds.), Governance, Corruption and Economic Performance. Washington DC: International Monetary Fund.

Emerson, P. (2006). Corruption, Competition and Democracy. Journal of Development Economics, 81, 193-212. http://dx.doi.org/10.1016/j.jdeveco.2005.04.005

Ervin, S. (1970). Separation of Powers: Judicial Independence. Law and Contemporary Problems, 35(1), 108-127.

Ferejohn, J. (1986). Incumbent performance and electoral control. Public Choice, 50, 5-25. http://dx.doi.org/10.1007/BF00124924.

Ferejohn, J., \& Kramer, L. (2006). Judicial Independence in a Democracy: Institutionalizing Judicial Restraint in Norms and the Law. New York: Cambridge University Press.

Fishman, R., \& Gatti, R. (2002). Decentralization and Corruption: Evidence across Countries. Journal of Public Economics, 83, 325-345. http://dx.doi.org/10.1016/S0047-2727(00)00158-4

Gerring, J., \& Thacker, A. (2004). Political Institutions and Corruption: The Role of Unitarism and Parliamentarism British Journal of Political Science, 34(2), 295-330. http://dx.doi.org/10.1017/S0007123404000067

Goldsmith, A. (1999). Slapping the Grasping Hand: Correlates of Political Corruption in Emerging Market. 
American Journal of Economics and Sociology, 58(4), 865-883. http://dx.doi.org/10.1111/j.1536-7150.1999.tb03398.x

Hanssen, A. (2004). Is There a Politically Optimal Level of Judicial Independence? The American Economic Review, 94(3), 712-729.

Hanssen, A. (1999). The Effect of Judicial Institutions on Uncertainty and the Rate of Litigation: The Election versus Appointment of State Judges. The Journal of Legal Studies, 28(1), 205-232. http://dx.doi.org/10.1086/468050

Jain, A. (1998). Economics of Corruption. Boston: Kluwer Academic Publishers.

Jain, A. (2001). Corruption: A Review. Journal of Economic Surveys, 15(1), 71-121. http://dx.doi.org/10.1111/1467-6419.00133

Kaufman, I. R. (1980). The Essence of Judicial Independence. Columbia Law Review, 80(4), 71-701. http://dx.doi.org/10.2307/1122136

LaPalombara, J. (1994). Structural and Institutional Aspects of Corruption. Social Research, 61(2), 325-350.

Larkins, C. (1996). Judicial Independence and Democratization: A Theoretical and Conceptual Analysis. The American Journal of Comparative Law, 44(4), 605-626. http://dx.doi.org/10.2307/840623

Lederman, D., Loayza, N., \& Soares, R. (2005). Accountability and Corruption: Political Institutions Matter. Economics and Politics, 17, 1-35. http://dx.doi.org/10.1111/j.1468-0343.2005.00145.x

Porta, R. L., López, F. C., Pop-Eleches, \& Shleifer, A. (2004). Judicial Checks and Balances. Journal of Political Economy, 445-470.

Mariscal, E., \& Sokoloff, K. (2000). Schooling, Suffrage, and the Persistence of Inequality in the Americas, 1800-1945. Political Institutions and Economic Growth in Latin America. Stanford: Hoover Institution.

Mauro, P. (1995). Corruption and Growth. The Quarterly Journal of Economics, 110(3), 681-712. http://dx.doi.org/10.2307/2946696

Mauro, P. (1998). Corruption and the Composition of Government Expenditure. Journal of Public Economics, $69,263-279$.

Montinola, G., \& Robert, J. (2002). Sources of Corruption: A Cross-Country Study. British Journal of Political Science, 32, 147-170. http://dx.doi.org/10.1017/S0007123402000066

Park, H. (2003). Determinants of Corruption: A Cross-National Analysis. The Multinational Business Review, 11(2), 29-48. http://dx.doi.org/10.1108/1525383X200300010

Persson, T., Roland, G., \& Tabellini, G. (1997). Separation of Powers and Political Accountability. Quarterly Journal of Economics, 112, 1163-1202. http://dx.doi.org/10.1162/003355300555457

Przeworski, A. (2007). Is the Science of Comparative Politics Possible? The Oxford Handbook of Comparative Politics. Oxford University Press.

Rios-Figueroa, J. (2006). Judicial Independence: Definition, Measurement, and Its Effects on Corruption. A dissertation submitted in partial fulfillment of the requirements for the degree of Doctor of Philosophy. Department of Politics, New York University.

Rosenberg, G. (1992). Judicial Independence and the Reality of Political Power. The Review of Politics, 54(3), 369-398.

Rose-Ackerman, S. (1978). Corruption: A Study in Political Economy. New York: Academic Press.

Rose-Ackerman, S. (1999). Corruption and Government: Causes, Consequences, and Reform. New York: Cambridge University Press.

Rose-Ackerman, S. (2006). International Handbook on the Economics of Corruption. Northampton, MA: Edward Elgar.

Rothschild, M., \& Stiglitz, J. (1976). Euqilibrium in Competitive Insurance Market: An Essay on the Economics of Imperfect Information. The Quarter Journal of Economics, 90(4), 629-649.

Russell, P., \& O'Brien, D. (2001). Judicial Independence in the Age of Democracy. Charlottesville and London: University Press of Virginia.

Sandholtz, W., \& Koetzle, W. (2000). Accounting for Corruption: Economic Structure, Democracy, and Trade. 
International Studies Quarterly, 44, 31-50.

Shi, S., \& Temzelides, T. (2004). A Model of Bureaucracy and Corruption. International Economic Review, 45(3), 2004.

Shleifer, A., \& Vishny, R. (1993). Corruption. The Quarterly Journal of Economics, 108(3), 599-617.

Svensson, J. (2005). Eight Questions about Corruption. Journal of Economic Perspectives, 19(3), 19-42.

Treisman, D. (1999). Decentralization and Corruption: Why are Federal States Perceived to be More Corrupt. Paper prepared for the presentation at the Annual Meeting of the American Political Science Association, Atlanta.

Treisman, D. (2000). The Causes of Corruption: A Cross-National Study. Journal of Public Economics, 76, 399-457.

Warren, M. (2006). Democracy and Deceit: Regulating Appearances of Corruption. American Journal of Political Science, 50(1), 160-174.

\section{Notes}

Note 1. By relating corruption to different features of the electoral system in a sample from the late nineties encompassing more than 80 democracies, Persson et al. (2001) find that larger voting districts are associated with less corruption, holding constant a variety of economic and social variables.

Note 2. Below are a few mathematical equations.

$2-1$,

$\mathrm{p}($ punishme $\mathrm{nt})=\mathrm{p}($ punishme $\mathrm{nt} \cap$ monitored $)+\mathrm{p}$ (punishme $\mathrm{nt} \cap$ Not monitored $)$

$=p($ punishme $\mathrm{nt} /$ monitor ed $) \times \mathrm{p}($ monitore $\mathrm{d})+$ $\mathrm{p}$ (punishme $\mathrm{nt} /$ Not monitored) $\times \mathrm{p}($ Not monitored $)$

$=1 \times \mathrm{p}($ monitore $\mathrm{d})+0$

$=\mathrm{p}($ monitore $\mathrm{d})$

$2-2$,

Let $g(\alpha)=\alpha-p_{D}(\alpha) \times \alpha_{d}$

$g(0)=0 ; g\left(\alpha_{0}\right)=\alpha_{0}-\alpha_{d}>0$

$g^{\prime}(\alpha)=1-p_{D}{ }^{\prime}(\alpha) \times \alpha_{d}$

$g^{\prime}\left(0^{+}\right)=0$

$g^{\prime \prime}(\alpha)<0$

$\Rightarrow g(\alpha)=\alpha-p_{D}(\alpha) \times \alpha_{d}>0$

$2-3$

(1) From ii $g^{\prime}(\alpha)=1-p_{D}{ }^{\prime}(\alpha) \times \alpha_{d}$, if $p^{\prime}(\alpha)<\frac{1}{\alpha_{d}}=(1-\delta) \times \pi \times W_{t}$, then institutional constraint $g(\alpha)=\alpha-p_{D}(\alpha) \times \alpha_{d}$ is a monotone increasing function of $\alpha$.

(2) From $V\left(p_{D}, \alpha\right)=\left(1-p_{D}(\alpha)\right) \times U\left(W_{0}+\alpha\right)+p_{D}(\alpha) \times U\left(W_{0}+\alpha-\alpha_{d}\right)$,

$$
\begin{aligned}
\frac{\partial V}{\partial \alpha}= & -p_{D}{ }^{\prime}(\alpha) \times U\left(W_{0}+\alpha\right)+\left(1-p_{D}(\alpha)\right) \times U^{\prime}\left(W_{0}+\alpha\right)+p_{D}{ }^{\prime}(\alpha) \times U\left(W_{0}+\alpha-\alpha_{d}\right) \\
& +p_{D}(\alpha) \times U^{\prime}\left(W_{0}+\alpha-\alpha_{d}\right)
\end{aligned}
$$




$$
\begin{aligned}
& \left.\frac{\partial V}{\partial \alpha}\right|_{\alpha=\alpha_{0-}}=-p_{D}{ }^{\prime}\left(\alpha_{0-}\right) \times U\left(W_{0}+\alpha_{0}\right)+p_{D}{ }^{\prime}\left(\alpha_{0-}\right) \times U\left(W_{0}+\alpha_{0}-\alpha_{d}\right)+U^{\prime}\left(W_{0}+\alpha_{0}-\alpha_{d}\right) \\
& \geq\left(1-p_{D}{ }^{\prime}\left(\alpha_{0-}\right)\right) \times U\left(W_{0}+\alpha_{0}-\alpha_{d}\right) \geq 0 \\
& \left.\frac{\partial^{2} V}{\partial \alpha^{2}}=-p_{D}{ }^{\prime \prime}(\alpha) \times U\left(W_{0}+\alpha\right)-p_{D}{ }^{\prime}(\alpha) \times U^{\prime}\left(W_{0}+\alpha\right)+U^{\prime \prime}\left(W_{0}+\alpha\right)-p_{D}{ }^{\prime}(\alpha)\right) \times U^{\prime}\left(W_{0}+\alpha\right) \\
& -p_{D}{ }^{\prime}(\alpha) \times U^{\prime \prime}\left(W_{0}+\alpha\right)+p_{D}{ }^{\prime \prime}(\alpha) \times U\left(W_{0}+\alpha-\alpha_{d}\right)+p_{D}{ }^{\prime}(\alpha) \times U^{\prime}\left(W_{0}+\alpha-\alpha_{d}\right) \\
& +p_{D}{ }^{\prime}(\alpha) \times U^{\prime}\left(W_{0}+\alpha-\alpha_{d}\right)+p_{D}(\alpha) \times U^{\prime \prime}\left(W_{0}+\alpha-\alpha_{d}\right) \\
& =2 p_{D}{ }^{\prime \prime}(\alpha) \times\left[U^{\prime}\left(W_{0}+\alpha-\alpha_{d}\right)-U^{\prime}\left(W_{0}+\alpha\right)\right]+p_{D}{ }^{\prime \prime}(\alpha) \times\left[U\left(W_{0}+\alpha-\alpha_{d}\right)-U\left(W_{0}+\alpha\right)\right] \\
& +\left(1-p_{D}(\alpha)\right) \times U^{\prime \prime}\left(W_{0}+\alpha\right)+p_{D}(\alpha) \times U^{\prime \prime}\left(W_{0}+\alpha-\alpha_{d}\right)
\end{aligned}
$$

Therefore, when

$$
r_{A}(\alpha)=-u^{\prime \prime}(\alpha) / u^{\prime}(\alpha) \leq \frac{p^{\prime \prime}(\alpha)}{2 p^{\prime}(\alpha)}+\frac{(1-p(\alpha)) U^{\prime \prime}\left(W_{0}+\alpha\right)+p(\alpha) U^{\prime \prime}\left(W_{0}+\alpha-\alpha_{d}\right)}{2 p^{\prime}(\alpha)\left[U\left(W_{0}+\alpha-\alpha_{d}\right)-U\left(W_{0}+\alpha\right)\right]}
$$

We have $\frac{\partial^{2} V}{\partial \alpha^{2}}<0$ and $\left.\frac{\partial V}{\partial \alpha}\right|_{\min }=\left.\frac{\partial V}{\partial \alpha}\right|_{\alpha=\alpha_{0-}} \geq 0$, which implies there is no Interior Solutions but a Corner Solution $\alpha=\alpha_{0}$.

$2-4$,

From

$$
\begin{aligned}
&\left\{\begin{array}{l}
M a x \\
\text { S.t. }
\end{array} \mathrm{W}_{0}+\alpha-p_{J}(\alpha), \alpha\right)=\left(1-p_{J}(\alpha)\right) \times U\left(W_{0}+\alpha\right)+p_{J}(\alpha) \times U\left(W_{0}+\alpha-J(\alpha)\right) \\
& \frac{\partial V}{\partial \alpha}=-p_{J}^{\prime}(\alpha) \times U\left(W_{0}+\alpha\right)+\left(1-p_{J}(\alpha)\right) \times U^{\prime}\left(W_{0}+\alpha\right)+p_{J}^{\prime}(\alpha) \times U\left(W_{0}+\alpha-J(\alpha)\right) \\
&+p_{J}(\alpha) \times\left(1-J^{\prime}(\alpha)\right) \times U^{\prime}\left(W_{0}+\alpha-J(\alpha)\right) \\
& V^{\prime}\left(0^{+}\right)= U^{\prime}\left(W_{0}\right)>0 \\
& \frac{\partial^{2} V}{\partial \alpha^{2}=}-p^{\prime \prime}(\alpha) \times U\left(W_{0}+\alpha\right)-p^{\prime}(\alpha) \times U^{\prime}\left(W_{0}+\alpha\right)-p^{\prime}(\alpha) \times U^{\prime}\left(W_{0}+\alpha\right)+(1-p(\alpha)) \times U^{\prime \prime}\left(W_{0}+\alpha\right) \\
&+p^{\prime \prime}(\alpha) \times U\left(W_{0}+\alpha-J(\alpha)\right)+p^{\prime}(\alpha) \times\left(1-J^{\prime}(\alpha)\right) \times U^{\prime}\left(W_{0}+\alpha-J(\alpha)\right) \\
&+\left(p^{\prime}(\alpha)-p^{\prime}(\alpha) \times J^{\prime}(\alpha)-p(\alpha) \times J^{\prime \prime}(\alpha)\right) \times U^{\prime}\left(W_{0}+\alpha-J(\alpha)\right) \\
&+p(\alpha) \times\left(1-J^{\prime}(\alpha)\right)^{2} \times U^{\prime \prime}\left(W_{0}+\alpha-J(\alpha)\right) \\
&=-p^{\prime \prime}(\alpha) \times\left(U\left(W_{0}+\alpha\right)-U\left(W_{0}+\alpha-J(\alpha)\right)\right)-2 p^{\prime}(\alpha) \times U^{\prime}\left(W_{0}+\alpha\right) \\
&+(1-p(\alpha)) \times U^{\prime \prime}\left(W_{0}+\alpha\right)+p^{\prime}(\alpha) \times\left(1-J^{\prime}(\alpha)\right) \times U^{\prime}\left(W_{0}+\alpha-J(\alpha)\right) \\
&+\left(p^{\prime}(\alpha)-p^{\prime}(\alpha) \times J^{\prime}(\alpha)-p(\alpha) \times J^{\prime \prime}(\alpha)\right) \times U^{\prime}\left(W_{0}+\alpha-J(\alpha)\right) \\
&+p(\alpha) \times\left(1-J^{\prime}(\alpha)\right)^{2} \times U^{\prime \prime}\left(W_{0}+\alpha-J(\alpha)\right) \\
&< 0
\end{aligned}
$$

Let $g(\alpha)=W_{0}+\alpha-J(\alpha)$ 


$$
\begin{aligned}
& g(0)=W_{0}>0 \\
& g\left(\alpha_{0}\right)=W_{0}+\alpha_{0}-J\left(\alpha_{0}\right)<0
\end{aligned}
$$

So there exits at least one $\alpha^{*} \in\left(0, \alpha_{0}\right)$ to let $g\left(\alpha^{*}\right)=W_{0}+\alpha^{*}-J\left(\alpha^{*}\right)=0$.

$g^{\prime}(\alpha)=1-p^{\prime}(\alpha) \times J(\alpha)-p(\alpha) \times J^{\prime}(\alpha)$

$g^{\prime}\left(0^{+}\right)=0$

$g^{\prime}\left(\alpha_{0}{ }^{-}\right)=1-p^{\prime}\left(\alpha_{0}^{-}\right) \times J\left(\alpha_{0}\right)-J^{\prime}\left(\alpha_{0}{ }^{-}\right)<0$

$g^{\prime \prime}(\alpha)=-p^{\prime \prime}(\alpha) \times J(\alpha)-2 p^{\prime}(\alpha) \times J^{\prime}(\alpha)-p(\alpha) \times J^{\prime \prime}(\alpha)<0$

Therefore, So there exits only one $\alpha^{*} \in\left(0, \alpha_{0}\right)$ to let $g\left(\alpha^{*}\right)=W_{0}+\alpha^{*}-J\left(\alpha^{*}\right)=0$ and for any $\alpha \in\left(0, \alpha^{*}\right)$, we have $W_{0}+\alpha-P(\alpha) J(\alpha)>0$, which means the bureaucrat might have an interior solution to maximize his utility function.

Since

$\left.\frac{\partial V}{\partial \alpha}\right|_{\alpha=\alpha^{*}}<0$

We must have one and only one $\alpha^{* *} \in\left(0, \alpha^{*}\right)$ and $V^{\prime}\left(\alpha^{* *}\right)=0$. At $\alpha^{* *}$, he can maximize his utility function.

\section{Copyrights}

Copyright for this article is retained by the author(s), with first publication rights granted to the journal.

This is an open-access article distributed under the terms and conditions of the Creative Commons Attribution license (http://creativecommons.org/licenses/by/3.0/). 